\title{
Why Non-accelerated Filers Voluntarily Comply with SOX 404b?
}

\author{
Zhenfeng Liu $P h D$ \\ Assistant Professor \\ School of Management \\ University of Michigan-Flint \\ Flint, MI, USA \\ E-mail:kelvinz@umich.edu \\ Yun Cheng $P h D$ \\ Assistant Professor \\ Richards College of Business \\ University of West Georgia \\ Carrollton, GA, USA \\ E-mail:ycheng@westga.edu \\ Ruonan Liu $P h D$ \\ Assistant Professor \\ Eberhardt School of Business \\ University of the Pacific \\ Stockton, CA, USA \\ E-mail: rliu@pacific.edu
}

Received: July I5, 2020

Accepted: July 30, 2020

Online Published: August I5, 2020

doi: I0.4628I/ijafr.v5i2.709

URL: https://doi.org/I0.4628I/ijafr.v5i2.709

\begin{abstract}
This paper investigates the managers' incentives to voluntarily comply with SOX 404b and the determinants of firms who voluntarily disclose SOX 404b internal control over financial reporting assessment. We find that voluntary SOX 404b reporting non-accelerated filers are more likely to receive effective internal control over financial reporting opinion than accelerated filers and large accelerated filers. We find that voluntary SOX 404b reporting non-accelerated filers are more likely to hire Big Four as independent auditors than non-SOX 404b reporting non-accelerated filers. We also predict and found substantially sufficient cases where non-accelerated filers which used to be, or ex-post became accelerated filers or large accelerated filers, and nonaccelerated filers with parent companies complying with SOX 404b are motivated to voluntarily comply with SOX 404b.
\end{abstract}

Keywords: SOX 404, Voluntary Disclosure, Internal Control over Financial Reporting, Big Four.

\section{Introduction}

The Sarbanes Oxley Act of 2002 (SOX) was enacted in the wake of the Enron and WorldCom accounting scandals. One of the most controversial provisions of SOX has been Section 404 regarding the management assessment of internal control over financial reporting (ICFR). SOX Section 404 (a) requires the management of public companies to assess and report on the effectiveness of the ICFR, and 404 (b) requires the external auditors to attest to and report on the adequacy of the management's assessment of ICFR. As the then SEC Chairman Christopher Cox said, the main purpose of Section 404 is to "provide meaningful disclosure to investors about the effectiveness of a company's internal controls systems, without creating unnecessary compliance burdens or wasting shareholder resources". Proponents praise the disclosure requirements, asserting that Section 404 has improved the quality of financial reporting and restored public confidence (Pong, Nagy, \& Cenker, 2007). However, critics argue that the costs associated with Section 404 exceed the benefits derived and that Section 404 has created an environment of "inefficient hyper-enforcement" (Grundfest \& Bochner, 2006). They point out that SOX can "undesirably 
reduce management risk-taking incentives, distort corporate disclosure, impede the flow of internal information, and reduce firms' ability to attract qualified managers and directors” (Ribstein, 2002; Romano, 2004; Holmstrom \& Kaplan, 2003). Some empirical evidence suggests that the costs related to its compliance are remarkably high and impose a significant burden on public companies (Raghunandan \& Rama, 2006; Zhang, 2007), especially impacting disproportionally on non-accelerated filers (companies with less than $\$ 75$ million in public float) (Zhang, 2007; Iliev, 20I0; Kinney \& Shepardson, 20I I).

The debate about compliance cost has led to concerns about extending the SOX compliance date and even a permanent exemption for non-accelerated filers. Unlike accelerated filers (companies with more than $\$ 75$ million but less than $\$ 700$ million in public float) and large accelerated filers (companies with more than $\$ 700$ million in public float) who have to comply with both Section 404 (a) and (b) for fiscal years ending on or after November I5, 2004, non-accelerated filers must comply with 404a from fiscal years ending after December I5, 2007. However, they were permanently exempted from Section 404(b) requirement.

Regarding the exemption for non-accelerated filers to comply with Section 404 (b), existing literature documents a prevailing phenomenon that firms which are slightly around accelerated filer definition threshold reduced their market float or retain their market float below the $\$ 75$ million threshold to avoid heavy compliance costs with 404 (b) (Gao, Wu, \& Zimmerman, 2009; Nondorf, Singer, \& You, 2012). However, to the best of our knowledge, few to none research have investigated the opposite phenomenon: there are still some non-accelerated filers who voluntarily have their external auditors to perform Section 404 (b) internal control audit, albeit its dramatically high compliance cost. Kinney and Shepardson (20I I) find that for small firms, rather than fully complying with SOX 404(b), management internal control reports and traditional financial audits have been cost-effective. Traditional audits without internal control weakness reports could also generate substantial weakness disclosure. Therefore, it seems counter-intuitive to comply with Section 404 (b) for non-accelerated filers.

We are interested in finding out the incentives for this voluntary disclosure behavior and general characteristics of firms disclosing internal control effectiveness reports voluntarily. We try to find whether they are doing this to maintain reputation, to correct misvalued stock price, to prepare for gaining or returning to the status of accelerated filers, or other unidentified yet possible reasons.

Using the sample firms during the first eight years of SOX 404 compliance, find that voluntary SOX $404 \mathrm{~b}$ reporting non-accelerated filers are more likely to receive effective internal control over financial reporting opinion than accelerated filers and large accelerated filers. We also find that voluntary SOX 404b reporting non-accelerated filers are more likely to hire Big Four as independent auditors than non-SOX $404 \mathrm{~b}$ reporting non-accelerated filers. We also predict and found substantially sufficient cases where non-accelerated filers which used to be, or ex-post became accelerated filers or large accelerated filers, and non-accelerated filers with parent companies complying with SOX 404b are motivated to voluntarily comply with SOX 404b.

This paper contributes to the literature in several ways. First, it adds to the disclosure literature by examining the benefits of voluntary disclosure and the incentives of managers to voluntarily comply with costly SOX 404b. Second, it adds to the SOX 404 literature by providing evidence whether SOX 404 meets its desired purpose and whether it incurs undesired consequences.

\section{Regulatory Background and Literature Review 2.I Regulatory Background}

The Sarbanes Oxley Act of 2002 (SOX) was passed in 2002 after a series of high profile corporate scandals. The law's main goal was to improve the quality of financial reporting and to increase investor confidence. In 2003, the SEC implemented Section 404 of SOX, which requires the management of public companies to assess and report on the effectiveness of the ICFR, and external auditors need to attest to and report on the adequacy of the management's assessment of ICFR. According to the SEC, Section 404 procedures are intended to help companies detect fraudulent reporting early and thus to deter financial fraud, directly improving the reliability of financial statements (SEC release 33-8238). The first SEC proposal requires all listed firms to comply with section 404 for fiscal years ending on or after September 15, 2003. However, due to adverse comments, the SEC deferred the accelerated filers' SOX 404 compliance to fiscal years ending on or after June I5, 2004, and non-accelerated filers' compliance to fiscal years ending on or after April 15, 2005 (Securities, 2004). The deadline kept being pushed forward, and the SEC finally requires that accelerate filers and large accelerated filers must comply with both Section 404a and 404b for fiscal years ending on or after November 15, 2004, and non-accelerated filers are not required by the SEC to comply with 404auntil fiscal years ending on or after December 15, 2007. But for non-accelerated filers to comply with SOX 404b, they were continually given an extension by the SEC until September 15, 2010, when President Obama signed into the "Dodd-Frank Wall Street Reform and Consumer Protection Act”-that permanently exempted non-accelerated filers from Section 404b requirement.

\subsection{Benefit of Voluntary Disclosure}

Voluntary disclosure is the dissemination of company information not mandated by disclosure regulations to the public or the investors. The theoretical literature argues that the managers disclose their private information to mitigate the adverse selection 
problem in the capital markets by reducing information asymmetry between the firm and investors, thus enabling greater liquidity and lowering transaction costs or non-diversifiable estimation risk (Verrecchia, I983; Diamond \& Verrecchia, I991; Coles, Loewenstein, \& Suay, 1995; Lang \& Lundholm, 2000; Francis, Khurana, \& Pereira, 2005; Jones, 2007; Shroff, Sun, White, \& Zhang, 2013; Schoenfeld, 2017). Prior empirical research papers also find that there is a relation between the level of disclosure and bid-ask spreads, information risk, litigation risk, and cost of capital (Welker, 1995; Botosan, I997; Botosan \& Plumlee, 2002; Cao \& Narayanamoorthy, 201 I; Hanley \& Hoberg, 2012; Houston, Lin, Liu, \& Wei, 2019). However, Cheynel (2013) finds that for disclosing and non-disclosing firms the relationship between voluntary disclosure and cost of capital is positive in aggregate. Similarly, Bertomeu, Beyer, and Dye (20II) develop a model of capital structure and suggest that cost of capital may not decrease due to more expansive voluntary disclosure. Additionally, Kim and Shi (201I) indicate the tone of voluntary disclosure tends to influence the effect of voluntary disclosure on the cost of capital and bad news forecast will increase the cost of equity capital while good news forecast doesn't significantly change the cost of capital. Finally, Francis, Nanda, and Olsson (2008) conclude that earnings quality instead of voluntary disclosure has the first-order effect on the lower level of cost of capital.

\subsection{Determinants of Firms with Voluntary Disclosure of Internal Control}

Three prior types of research relate most closely to our research question on the determinants of firms that voluntarily disclose their report on internal control. McMullen, Raghunandan, and Rama (I996) find that smaller firms that were subject to SEC enforcement actions or incurred financial restatements are less likely to provide voluntary disclosure on internal control. Bronson, Carcello, and Raghunandan (2006) use 397 midsized firms in 1998 as sample firms and find that the voluntary internal control disclosure firms generally are larger, have more meetings in the audit committee, are higher in the level of institutional ownership, and grow more rapidly in sales. Basu, Krishnan, Lee, and Zhang (2018) find that even being exempted from SOX 404b requirements at the time of IPO; many firms still proactively disclose material internal control weakness before going public. These firms generally have higher litigation risk, hire auditors that are industry specialists, and are more likely to have an audit committee before IPO.

\section{Hypotheses Development}

SOX $404 \mathrm{~b}$ is reported to be the most costly provision by both practitioners and researchers. While accelerated filers and large accelerated filers (hereafter referred to as AFLAF) have no choice but to comply with SOX 404b, there are two options for nonaccelerated filers (hereafter referred to as NAF) to choose: comply or not. If the firm chooses to comply with $404 \mathrm{~b}$, it has to incur large cost in compliance during the first year due to the demand for increasing process and control documentation for high-risk processes. Firms, by nature, exist to make a profit. If compliance with $404 \mathrm{~b}$ does not generate future benefits to the firm, the firm would not choose to comply. That is to say, if the firm let the independent auditor attest to the management report on ICFR, and get a negative opinion, the market would have a negative reaction to its stock price. In this way, the firm incurs double loss - compliance cost and market price decrease. Therefore, for any rational firm, if it anticipates negative opinion on SOX 404b, they would otherwise choose not to comply with it. On the other hand, if the firm has confidence in its ICFR, and expects positive opinion on SOX 404b, it would be more willing to comply with it because it is giving the market a signal that they have high-quality ICFR. Therefore, our first hypothesis is:

Hi: Firms voluntarily complying with SOX $404 \mathrm{~b}$ are more likely to receive positive ICFR opinions.

Big-N auditors are identified in the literature as higher quality auditors as they have the technological capability in detecting earnings management, and when detected, there is a higher probability that they will report it. Many studies (Dopunch \& Simunic, I982; DeAngelo, I98I) have postulated product differentiation in the audit market, specifically, that large audit firms (the Big Eight) provide higher quality audit services than those provided by smaller audit firms. Non-accelerated filers who voluntarily comply with SOX 404b normally want to show their high quality of internal control, so they are likely to choose Big-4 to confirm their high quality. Therefore, our second hypothesis is:

H2: Firms voluntarily complying with SOX $404 \mathrm{~b}$ are more likely to use Big-4 as independent auditors.

Holmstrom and Kaplan (2003) argue that much of the compliance costs of SOX are fixed. Since the firm would have already incurred the major portion of costs in the first year of compliance, the compliance costs in subsequent years are unlikely to be significant. Thus, if a firm has already complied with SOX $404 \mathrm{~b}$ when it was a large accelerated filer or accelerated filer, and changed to the non-accelerated filer, it would be willing to comply with SOX 404b for some reasons. First, with little incremental compliance cost, it would benefit from voluntary disclosure on ICFR from the capital market. Second, if the firm anticipates that it would return to the accelerated filer or large accelerated filers in the future, the continued compliance with SOX $404 \mathrm{~b}$ is a good signal to the market. 
On the other hand, if a firm prepares to expand and anticipates to become an accelerated filer or large accelerated filer in the next year or later, they might also be willing to comply with SOX $404 \mathrm{~b}$ when they are not supposed to because voluntary disclosure brings about the aforesaid benefits while mandatory disclosure does not. Therefore, our third hypothesis is:

$\mathrm{H}_{3}$ : Formerly accelerated filers and large accelerated filers are motivated to voluntarily comply with SOX 404b when they become non-accelerated filers.

$\mathrm{H}_{3 \mathrm{~b}}$ : Non-accelerated filers who anticipate becoming accelerated filers or large accelerated filers are more motivated to voluntarily comply with SOX 404 b.

Many firms that have subsidiary firms file combined IO-K form to the SEC. Among all the subsidiary firms, several of them might also be listed companies. When the parent company performs SOX 404b auditing, the subsidiary firms have to also go through the whole process of SOX 404b auditing "passively". They had no other choice but to incur the compliance cost, so it is to their best benefit to also issue SOX $404 \mathrm{~b}$ report "voluntarily". Although it seems to be voluntary compliance, the fact is that they take a ride from the parent company and enjoy the benefit of voluntary disclosure. Therefore, our fourth hypothesis is:

H4: Firms with parent companies that are accelerated filers or large accelerated filers are motivated to voluntarily comply with SOX 404 b.

\section{Sample, Model, and Variables \\ 4.I Sample}

The sample firms we examine in this study are listed domestic companies in the United States from 2003 to 2012 . Auditing related information and firm filer status are collected from Audit Analytics, and firm financial information is collected from COMPUSTAT.

\subsection{Model}

For Hypothesis I, we use the following logistic regression model:

$$
\operatorname{Pr}(\mathrm{MW}=0)=\gamma_{0}+\gamma_{1}{ }^{*} \mathrm{VD}+\gamma_{2}{ }^{\star 2 N T A}+\gamma_{3}{ }^{\star 2} \mathrm{LOSS}+\gamma_{\text {(Industry Controls })}+\mu
$$

For Hypothesis 2, we regress the probability of voluntary SOX $404 \mathrm{~b}$ compliance on firm characteristics and control variables, using the following logit regression:

$\operatorname{Pr}(\mathrm{VD}=\mathrm{I})=\beta_{1}+\beta_{2} \times \mathrm{BIG} 4+\beta_{2}{ }^{*} \mathrm{LNTA}+\beta_{3}{ }^{\star} \operatorname{LOSS} \beta_{\text {(Industry Controls })}+\varepsilon$

Where:

$$
\begin{aligned}
& \text { MW = I if the firm has material weakness in IFRC; } \\
& \text { VD = I if the firm voluntarily complies with } 404 \mathrm{~b} \text {, else } 0 ; \\
& \text { BIG4 = I if the firm uses Big } 4 \text { auditor, else 0; } \\
& \text { LOSS = I if negative earnings, else I; } \\
& \text { LNTA = natural log of total assets at year-end; }
\end{aligned}
$$

For Hypothesis 3 and Hypothesis 4, descriptive statistics would suffice as we only need documented phenomenon to support these two hypotheses.

\section{Empirical Findings}

Table I presents the descriptive statistics of firms filing SOX 404a and 404b during the first 8 SOX compliance year, with the first compliance year being fiscal year-ends that fall in the range of November 15, 2004, to November I4, 2005. The results show that from year I to year 3 because 404a is mandatory only for AFLAF, the number of 404a reports remains low at around 4000 , and from year 4 on, the 404 a reports suddenly go up to double the number in year 3 , because NAF is mandated to provide 404a reports from year 4 on. For 404b reports, the number goes up from 3697 to 3906 from year I to year 3, but drops gradually to 3345 from year 4 to year 8 , which arguably could be because the financial crisis caused many firms either go private or downsized to NAF, who does not have the responsibility to provide $404 \mathrm{~b}$ reports. 
Table I. Descriptive statistics of firms filing SOX 404a and 404b

\begin{tabular}{lllllllll}
\hline SOX Year & I & 2 & 3 & 4 & 5 & 6 & 7 & 8 \\
\hline $404 \mathrm{a}$ & 37 I I & 3847 & 4006 & 8096 & 8068 & 7675 & 7363 & 7045 \\
\hline $404 \mathrm{~b}$ & 3697 & 3788 & 3855 & 3906 & 3749 & 3599 & 3352 & 3345 \\
\hline
\end{tabular}

Note: The first SOX year is fiscal year-ends that fall in the range of November I5, 2004, to November I4, 2005.

Table 2 presents the basic statistics for effective internal control over financial reporting opinions. Panel A presents the descriptive statistics of internal control effectiveness, and the percentage comparison of not-effective firms is presented in Panel B and Figure I. The results show that, in the first three years of SOX $404 \mathrm{~b}$ compliance, voluntary NAF have a statistically lower percentage of obtaining "non-effective ICFR" opinion than AFLAF, with the percentage being 6.45\% vs. $18.19 \%$ in year I, $10.13 \%$ vs. $12.92 \%$ in year 2 , and $7.89 \%$ vs. $10.38 \%$ in year 3 . This partially supports our hypothesis $\mathrm{I}$. However, during the later years, there is no clear pattern of whether NAF gets more percentage of effective ICFR opinion than the AFLAF or the other way around. It might not necessarily go against our hypothesis, because it might not be because more "bad" NAFs are voluntarily complying with SOX 404b, but because more AFLAF have modified their weakness in ICFR and the relative percentage difference becomes smaller. Figure I presents this view: the "not effective opinion" rate is plunging for AFLAF from $18.19 \%$ in year I to $4.40 \%$ in year 5 and remains around $4 \%$ during year 6 to year 8 . However, this pattern does not apply for NAF. This result is also consistent with the notion of "diseconomies of scale", which contends that larger firms have more financial resources and better infrastructure to mitigate the weakness of internal control over financial reporting over time.

Table 2. Basic Statistics for Effective ICFR Opinions

Panel A: Descriptive statistics of internal control effectiveness

\begin{tabular}{|c|c|c|c|c|c|c|c|c|}
\hline SOX Year & $\bar{I}$ & 2 & 3 & 4 & 5 & 6 & 7 & 8 \\
\hline \multicolumn{9}{|l|}{$N A F$} \\
\hline No & 4 & 8 & 6 & $\mathrm{IO}$ & 9 & 6 & 7 & I0 \\
\hline Yes & 58 & $7 \mathrm{I}$ & 70 & IIO & $\mathrm{I} 40$ & $27 \mathrm{I}$ & 179 & 123 \\
\hline Total & 62 & 79 & 76 & 120 & $\mathrm{I} 49$ & 277 & 186 & I33 \\
\hline \multicolumn{9}{|l|}{$A F L A F$} \\
\hline No & 495 & 354 & 291 & 225 & II5 & 80 & 72 & 93 \\
\hline Yes & 2226 & 2385 & 2512 & 2572 & 2501 & 2320 & 2250 & 2264 \\
\hline Total & 2721 & 2739 & 2803 & 2797 & 2616 & 2400 & 2322 & 2357 \\
\hline Grand total & 2783 & 2818 & 2879 & 2917 & 2765 & 2677 & 2508 & 2490 \\
\hline
\end{tabular}

Panel B: Comparison of percentage of not effective firms

\begin{tabular}{lllllllll}
\hline SOX Year & I & 2 & 3 & 4 & 5 & 6 & 7 & 8 \\
\hline NAF No (\%) & 6.45 & I0.13 & 7.89 & 8.33 & 6.04 & 2.17 & 3.76 & 7.52 \\
\hline Large No (\%) & 18.19 & 12.92 & 10.38 & 8.04 & 4.40 & 3.33 & 3.10 & 3.95 \\
\hline
\end{tabular}

Note: NAF refers to "non-accelerated filers", and AFLAF refers to "accelerated filers and large accelerated filers". 


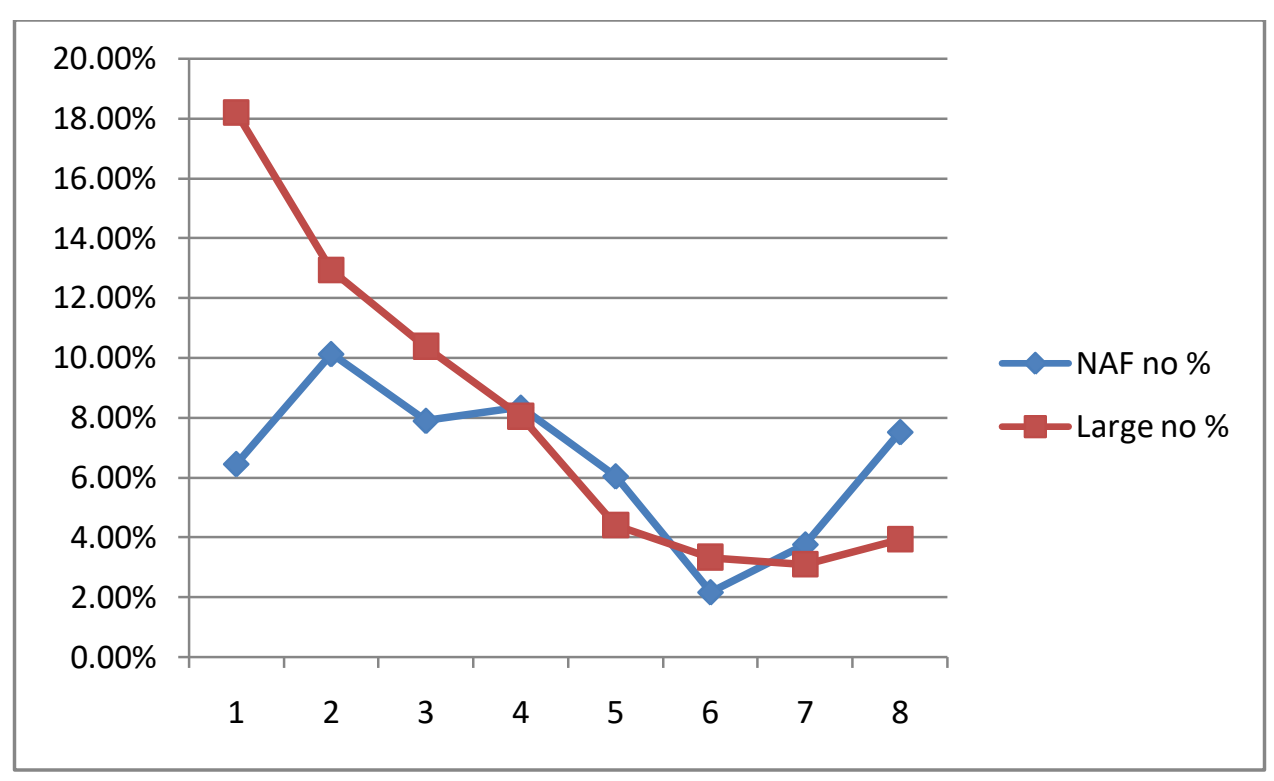

Figure I. Comparison of percentage of not effective firms

Table 3 presents descriptive statistics of types of voluntary compliance firms. The column "Momentum" provides support to our Hypothesis 3, which predicts that NAFs that used to be AFs or LAFs or ex-post become AFs or LAFs are motivated to voluntarily comply with $404 \mathrm{~b}$. From year I to year 6 , the number of these NAF increased from I3 to I80, and this could be due to two reasons. First, as the SOX years go on, the more valuable practice of mitigating internal control weakness has been developed by larger firms, so NAF that anticipate becoming AFLAF are more willing to comply with $404 \mathrm{~b}$ with more guidance and less unnecessary costs. Second, years 4, 5, and 6 are the years of the financial crisis, so more AFLAF downsized to NAF but they still comply with 404b because it incurs little to none marginal costs for them. However, in year 7 and year 8 the number of momentum firms jumped to I08 and 52, which may be due to the comeback of economy pulling those used-to-beAFLAF NAFs back to AFLAF status again. The "Parent" column in Table 3 provides support for Hypothesis 4 . There are 24 to $39 \mathrm{NAF}$ during the 8 SOX years who have their parent company as AFLAF and include their financial statements in the AFLAF's I0-K annual report. As the parent companies must comply with $404 \mathrm{~b}$, the NAF are subject to $404 \mathrm{~b}$ in a compulsory manner. Therefore they passively complied with $404 \mathrm{~b}$. The "Pure Voluntary" column provides preliminary evidence to support our Hypothesis I. The pure voluntary disclosure NAF almost all get effective internal control over financial reporting opinion, except for the $8^{\text {th }}$ year. These firms remain the status of NAF and they seem to be excellent NAF among others in terms of effective internal control over financial reporting, so they are confident to provide the $404 \mathrm{~b}$ reports.

Table 3. Descriptive statistics of types of voluntary compliance firms

\begin{tabular}{lllll}
\hline SOX year & Momentum & Parent & $\begin{array}{l}\text { Pure Voluntary } \\
\text { (Not effective ICFR) }\end{array}$ & Total \\
\hline $\mathrm{I}$ & $\mathrm{I} 3$ & 24 & $25(2)$ & 62 \\
\hline 2 & 29 & 24 & $26(2)$ & 79 \\
\hline 3 & 26 & 26 & $24(0)$ & 76 \\
\hline 4 & 65 & 29 & $26(\mathrm{I})$ & $\mathrm{I} 20$ \\
\hline 5 & 93 & 31 & $25(2)$ & $\mathrm{I} 49$ \\
\hline 6 & 180 & 39 & $58(0)$ & 277 \\
\hline 7 & 108 & 29 & $49(2)$ & $\mathrm{I} 86$ \\
\hline 8 & 52 & 29 & $52(\mathrm{IO})$ & $\mathrm{I33}$ \\
\hline
\end{tabular}

Note: "Parent" means the firm has a parent company which is a large accelerated filer; "Momentum" means the following three circumstances: I) the firm used to be an accelerated filer and then becomes non-accelerated filer, and then returns to the status of the accelerated filer, and it voluntarily complies with SOX 404b at least once during its non-accelerated filer status; 2) the firm voluntarily complies with SOX $404 \mathrm{~b}$ before it becomes accelerated filer; 3 ) the firm used to be accelerated filer and also complied with SOX $404 \mathrm{~b}$ at least for one year; "Pure Voluntary" means the firm does not qualify for any aforementioned types of voluntary compliance. 
Table 4 Panel A presents descriptive statistics of firms' independent auditor choice, and the comparison is presented in Panel B and Figure 2. The results show that during the 8 SOX compliance years, $78.20 \%$ to $91.94 \%$ of the voluntary NAFs employ the Big Four accounting firms as their independent auditors, but in contrast, only $18.09 \%$ to $44.05 \%$ or the non-voluntary NAFs hire Big Fours. It is very clear that voluntary SOX 404b reporting NAFs are significantly more likely to use Big Four as independent auditors than non-voluntary SOX 404b reporting NAF. This supports our hypothesis 4 , and we will also revisit this hypothesis using multivariate regression.

Table 4. Basic Statistics of NAFs' Auditor Choice

Panel A: Descriptive statistics of $N A F^{\prime}$ ' independent auditor choice

\begin{tabular}{lllllllll}
\hline SOX Year & I & 2 & 3 & 4 & 5 & 6 & 7 & 8 \\
\hline Voluntary & & & & & & & & \\
\hline Big 4 & 57 & 67 & 68 & 94 & I20 & 225 & I46 & I04 \\
\hline Non-Big 4 & 5 & I2 & 8 & 26 & 29 & 52 & 40 & 29 \\
\hline Total & 62 & 79 & 76 & I20 & I49 & 277 & I86 & I33 \\
\hline Non-voluntary & & & & & & & & 522 \\
\hline Big 4 & I305 & 976 & 766 & 649 & 594 & 500 & 541 & 5296 \\
\hline Non-Big 4 & 2372 & I445 & 973 & I448 & 2651 & 2543 & 2449 & 2296 \\
\hline Total & 3677 & 2421 & I739 & 2097 & 3245 & 3043 & 2990 & 2818 \\
\hline Grand total & 3739 & 2500 & I8I5 & 2217 & 3394 & 3320 & 3176 & 2951 \\
\hline
\end{tabular}

Panel B: Comparison of NAFs' percentage of choosing Big Four as auditors

\begin{tabular}{lllllllll}
\hline SOX Year & I & 2 & 3 & 4 & 5 & 6 & 7 & 8 \\
\hline Voluntary & $91.94 \%$ & $84.81 \%$ & $89.47 \%$ & $78.33 \%$ & $80.54 \%$ & $81.23 \%$ & $78.49 \%$ & $78.20 \%$ \\
\hline Non-voluntary & $35.49 \%$ & $40.31 \%$ & $44.05 \%$ & $30.95 \%$ & $18.31 \%$ & $16.43 \%$ & $18.09 \%$ & $18.52 \%$ \\
\hline
\end{tabular}

Note: "Big 4" refers to the international Big 4 accounting firms, and "Non-Big 4" refers to the other accounting firms.

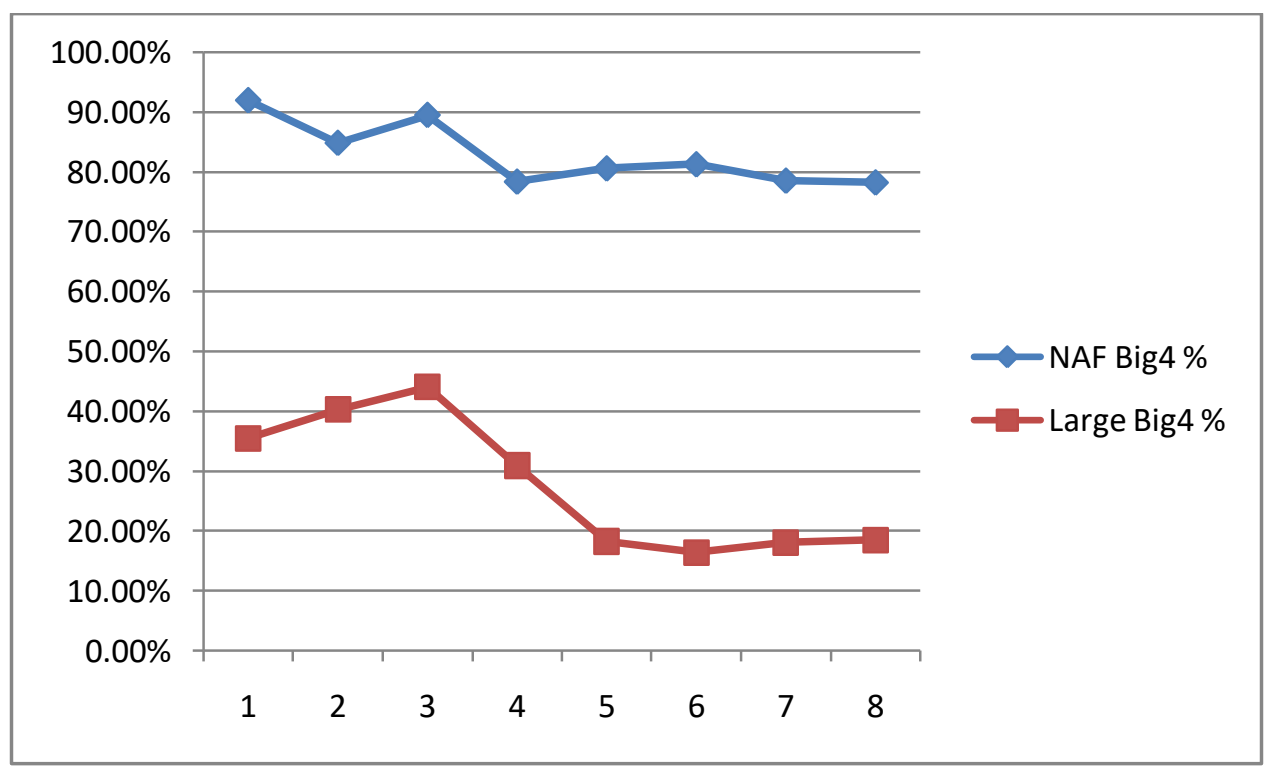

Figure 2. Comparison of firms' percentage of choosing Big Four as auditors

Table 5 presents the empirical result from the first regression model which tests whether voluntary NAF receives a lower percentage of ineffective internal control over financial reporting opinions. As we can see from the result, VD's coefficient is positive (coefficient $=0.5533$ ) and significant at a $\mathrm{I} \%$ level, which means that if firms voluntarily comply with $404 \mathrm{~b}$, the 
probability of getting effective internal control opinion is higher. Therefore, we can conclude that the data in the univariate test and multivariate test both support our Hypothesis I.

Table 5. Empirical results for Hypothesis I with the regression

$$
\operatorname{Pr}(\mathrm{MW}=0)=\gamma_{0}+\gamma_{1}{ }^{*} \mathrm{VD}+\gamma_{2}{ }^{*} \mathrm{LNTA}+\gamma_{3}{ }^{\star} \mathrm{LOSS}+\gamma_{(\text {Industry Controls })}+\mu
$$

\begin{tabular}{lll}
\hline \multicolumn{1}{c}{ Parameter } & Estimate & P-value \\
\hline Intercept & -5.6877 & 0.979 \\
\hline VD & 0.5533 & $0.002 \mathrm{I}$ \\
\hline LNTA & 0.2136 & $<.000 \mathrm{I}$ \\
\hline LOSS & -0.7448 & $<.000 \mathrm{I}$ \\
\hline Industry & Yes & \\
Effect & & \\
\hline No. of & I6037 & \\
\hline Observations & & \\
\hline $\mathrm{R}^{2}$ & 0.0237 &
\end{tabular}

Note: This table presents regression of the probability of no material weakness (MW=0) on whether the firm voluntarily complies with SOX 404b (VD). Coefficients and P values are provided in the table.

Table 6 presents the empirical result from the second regression model which tests whether voluntary NAFs are more likely to hire Big Fours as their independent auditors. As we can see from the results, the coefficient of Big4 (coefficient $=$ 0.7443 ) is positive and significant at $\mathrm{I} \%$ level, indicating that the likelihood of NAFs hiring Big Fours is significantly higher than the non-voluntary NAF. Therefore, we can conclude that the univariate test and the multivariate test both support our Hypothesis 4.

Table 6. Empirical results for Hypothesis 4 with the regression

\begin{tabular}{lll}
$\operatorname{Pr}(\mathrm{VD}=\mathrm{I})=\beta_{1}+\beta_{2} \times \mathrm{BIG} 4+\beta_{2}{ }^{*} \mathrm{LNTA}+\beta_{3}{ }^{\star} \mathrm{LOSS} \boldsymbol{\beta}_{\text {(Industry Controls })}+\varepsilon$ & \\
\hline Parameter & Estimate & P-value \\
\hline Intercept & $-\mathrm{I3.3632}$ & 0.9496 \\
\hline Big4 & 0.7443 & $<.000 \mathrm{I}$ \\
\hline LNTA & $0.4 \mathrm{I} 84$ & $<.000 \mathrm{I}$ \\
\hline loss & $0.3 \mathrm{I} 83$ & \\
\hline Industry Effect & Yes & \\
\hline No. of Observations & 9835 & \\
\hline $\mathrm{R}^{2}$ & 0.1065 & \\
\hline
\end{tabular}

Note: This table presents regression of the probability of voluntary compliance with SOX 404b (VD) on whether the firm hires Big Four accounting firms (Big4) as the independent auditor. Both of the variables are indicatory variables, where they take $\mathrm{I}$ if that happens, and 0 otherwise. Coefficients and $\mathrm{P}$ values are provided in the table.

Taken together, the descriptive statistics and the empirical test results support our four hypotheses. Nonaccelerated filers that used to be, or ex-post became accelerated filers or large accelerated filers, and non-accelerated filers with parent companies complying with SOX 404b are motivated to voluntarily comply with SOX 404b. Voluntary SOX 404b reporting non-accelerated filers are more likely to receive effective internal control over financial reporting opinion and more likely to hire Big Four as independent auditors than accelerated filers and large accelerated filers.

\section{Conclusion and Future Research}

This paper investigates the managers' incentives to voluntarily comply with SOX $404 \mathrm{~b}$ and the determinants of firms who voluntarily disclose SOX 404b ICFR assessment. Using the first eight years of SOX 404 compliance data, we find that voluntary SOX 404b reporting non-accelerated filers are more likely to receive effective internal control over financial reporting 
opinion than accelerated filers and large accelerated filers. We find that voluntary SOX 404b reporting non-accelerated filers are more likely to hire Big Four as independent auditors than non-SOX $404 \mathrm{~b}$ reporting non-accelerated filers. We predict and found many cases confirming that firms that used to be, or ex-post became accelerated filers or large accelerated filers, and firms with parent company complying with SOX 404b are motivated to voluntarily comply with SOX 404b. Future research could study the voluntary compliance issue for foreign firms listed in the U.S. to check whether the behavior of 20-F issuers is different from $\mathrm{IO}-\mathrm{K}$ issuers.

\section{References}

Basu, S., Krishnan, J., Lee, J. E., \& Zhang, Y. (2018). Economic Determinants and Consequences of the Proactive Disclosure of Internal Control Weaknesses and Remediation Progress in IPOs. Auditing: A Journal of Practice \& Theory, 37(4), I- 24 .

Bertomeu, J., Beyer, A., \& Dye, R. A. (20II). Capital structure, cost of capital, and voluntary disclosures. The Accounting Review, 86(3), 857-886.

Botosan, C. A. (1997). Disclosure level and the cost of equity capital. Accounting review, 323-349.

Botosan, C. A., \& Plumlee, M. A. (2002). A re-examination of disclosure level and the expected cost of equity capital. Journal of accounting research, $40(\mathrm{I}), 2 \mathrm{I}-40$.

Bronson, S. N., Carcello, J. V., \& Raghunandan, K. (2006). Firm characteristics and voluntary management reports on internal control. Auditing: A Journal of Practice \& Theory, 25(2), 25-39.

Cao, Z., \& Narayanamoorthy, G. S. (20II). The effect of litigation risk on management earnings forecasts. Contemporary Accounting Research, 28(I), I25-I73.

Cheynel, E. (2013). A theory of voluntary disclosure and cost of capital. Review of Accounting Studies, I8(4), $987-1020$.

Coles, J. L., Loewenstein, U., \& Suay, J. (I995). On equilibrium pricing under parameter uncertainty. Joumal of Financial and Quantitative analysis, 347-364.

DeAngelo, L. E. (I98I). Auditor size and audit quality. Journal of accounting and economics, 3(3), I83-199.

Diamond, D. W., \& Verrecchia, R. E. (I99I). Disclosure, liquidity, and the cost of capital. The journal of Finance, 46(4), I325-I359.

Dopunch, N., \& Simunic, D. (1982). The competition in auditing an assessment fourth symposium on auditing research. University of Illinois.

Francis, J., Nanda, D., \& Olsson, P. (2008). Voluntary disclosure, earnings quality, and cost of capital. Journal of accounting research, 46(I), 53-99.

Francis, J. R., Khurana, I. K., \& Pereira, R. (2005). Disclosure incentives and effects on cost of capital around the world. The accounting review, $80(4)$, II25-II 62.

Gao, F., Wu, J. S., \& Zimmerman, J. (2009). Unintended consequences of granting small firms exemptions from securities regulation: Evidence from the Sarbanes-Oxley Act. Journal of Accounting Research, 47(2), 459-506.

Grundfest, J. A., \& Bochner, S. E. (2006). Fixing 404. Mich. L. Rev., I05, I643.

Hanley, K. W., \& Hoberg, G. (2012). Litigation risk, strategic disclosure and the underpricing of initial public offerings. Journal of Financial Economics, IO3(2), 235-254.

Holmstrom, B., \& Kaplan, S. N. (2003). The state of US corporate governance: What's right and what's wrong?. Journal of Applied Corporate Finance, I5(3), 8-20.

Houston, J. F., Lin, C., Liu, S., \& Wei, L. (2019). Litigation risk and voluntary disclosure: Evidence from legal changes. The Accounting Review, 94(5), 247-272.

Iliev, P. (2010). The effect of SOX Section 404: Costs, earnings quality, and stock prices. The journal of finance, 65(3), II 63I 196.

Jones, D. A. (2007). Voluntary disclosure in R\&D-intensive industries. Contemporary Accounting Research, $24(2), 489-522$.

Kim, J. W., \& Shi, Y. (20II). Voluntary disclosure and the cost of equity capital: Evidence from management earnings forecasts. Journal of Accounting and Public Policy, 30(4), 348-366.

Kinney, JR, W. R., \& Shepardson, M. L. (20II). Do control effectiveness disclosures require SOX 404 (b) internal control audits? A natural experiment with small US public companies. Joumal of Accounting Research, 49(2), 4I3-448.

Lang, M. H., \& Lundholm, R. J. (2000). Voluntary disclosure and equity offerings: reducing information asymmetry or hyping the stock?. Contemporary accounting research, I7(4), 623-662.

McMullen, D. A., Raghunandan, K., \& Rama, D. V. (1996). Internal control reports and financial reporting problems. Accounting Horizons, IO(4), 67.

Nondorf, M. E., Singer, Z., \& You, H. (2012). A study of firms surrounding the threshold of Sarbanes-Oxley Section 404 compliance. Advances in Accounting, 28(I), 96-IIO. 
Pong, C., Nagy, A. L., \& Cenker, W. J. (2007). Accounting firms cautiously maneuver in the new audit environment-a note. Managerial Auditing Journal.

Raghunandan, K., \& Rama, D. V. (2006). SOX Section 404 material weakness disclosures and audit fees. Auditing: A Joumal of Practice \& Theory, 25(I), 99-II4.

Ribstein, L. E. (2002). Market vs. regulatory responses to corporate fraud: A critique of the Sarbanes-Oxley Act of 2002. J. Corp. L., 28, I.

Romano, R. (2004). The Sarbanes-Oxley Act and the making of quack corporate governance. Yale LJ, II4, I52I.

Schoenfeld, J. (2017). The effect of voluntary disclosure on stock liquidity: New evidence from index funds. Journal of Accounting and Economics, 63(I), 5I-74.

Shroff, N., Sun, A. X., White, H. D., \& Zhang, W. (2013). Voluntary disclosure and information asymmetry: Evidence from the 2005 securities offering reform. Joumal of Accounting Research, 5I(5), I299-I345.

Securities, U. S. (2004). Exchange Commission (SEC). 2003. Acceleration of periodic report filing dates and disclosure concerning website access to reports. September, 5.

Verrecchia, R. E. (1983). Discretionary disclosure. Journal of accounting and economics, 5, I79-I94.

Welker, M. (1995). Disclosure policy, information asymmetry, and liquidity in equity markets. Contemporary accounting research, $I I(2), 80 I-827$.

Zhang, I. X. (2007). Economic consequences of the Sarbanes-Oxley Act of 2002. Journal of accounting and economics, 44(I2), 74-II5.

\section{Copyrights}

Copyright for this article is retained by the author(s), with first publication rights granted to the journal. This is an open-access article distributed under the terms and conditions of the Creative Commons Attribution license (http://creativecommons.org/licenses/by/4.0/). 